\title{
Pengaruh Kompetensi dan Karakter Dosen Terhadap Metode Pembelajaran Serta Dampaknya Kepada Kinerja Dosen di Universitas Subang
}

\section{Taufiq Hidayat}

Fakultas Ilmu Administrasi, Universitas Subang

Opieqhsb.74@gmail.com

\begin{abstract}
Abstrak
Tujuan penelitian ini adalah untuk mengetahui dan menganalisis: (1) Kompetensi Dosen, (2) Karakter Dosen, (3) Metode Pembelajaran, dan (4) Kinerja Dosen, serta (5) Pengaruh Kompetensi Dosen, Karakter Dosen dan Teknik Pembelajaran terhadap Kinerja Dosen di Universitas Subang Kabupaten Subang Jawa Barat. Metode penelitian yang digunakan dalam penelitian adalah metode penelitian assosiatif dengan proses kualitatif dan pendekatan action research. Dan unit analisis dalam penelitian adalah Mahasiswa Universitas Subang Jawa Barat dengan sampel sebanyak 100 orang. Dalam Penelitian ini, ukuran sampel ditentukan oleh bentuk uji statistik dan yang digunakan adalah Analisis Jalur (Path Analisis), dan untuk menentukan ukuran sampel minimal pada koefisien korelasi yang dilakukan secara iterative (perhitungan berulang ulang).Berdasarkan hasil penelitian, diperoleh bahwa Kompetensi serta Karakter Dosen sangat memberikan pengaruh terhadap Metode Pembelajaran yang akan diberikan oleh Dosen kepada mahasiswa. Dosen-dosen yang sudah ada harus lebih meningkatkan Kompetensinya dengan Karakter yang kuat dalam berhadapan dengan Mahasiswa karena memberikan pengaruh baik secara simultan maupun secara parsial terhadap Metode Pembelajaran yang lebih hidup dan bervariatif yang akan diberikan kepada Mahasiswa. Hal ini berdampak kepada baik atau tidaknya kinerja Dosen di Universitas Subang.
\end{abstract}

Kata Kunci : kompetensi, karakter dosen, metode pembelajaran, kinerja dosen

\section{Abstrct}

The purpose of this research was to determine and analyze: (1) Lecturer Competence, (2) Lecturer Character, (3) Learning Method, and (4) Lecturer Performance, and (5) Effect of Lecturer Competence, Lecturer Character and Learning Techniques on Lecturer Performance at the University of Subang, Subang Regency, West Java. This research method used in research is an associative research method with a qualitative process and action research approach. And the unit of analysis in this study is the Students of Subang University, West Java with a sample of 100 people. In this study, the sample size is determined by the form of statistical tests and the 
Path Analysis is used, and to determine the minimum sample size on the correlation coefficient which is done iteratively (repeated calculations). Based on the results of the study, it was found that the Competence and Character of the Lecturer greatly influenced the Learning Method to be provided by the Lecturer to students. Existing lecturers must further enhance their competence with strong character in dealing with students because they provide both simultaneous and partial influence on the more lively and varied Learning Methods that will be given to students. This has an impact on whether or not the performance of Lecturers at the University of Subang.

Keywords : competence, lecturer Character, learning method, lecturer performance

\section{Pendahuluan}

Hermanto Halil dalam jurnalnya yang berujudul Peran Perguruan Tinggi dalam pembangunan daerah menjelaskan bahwa perguruan tinggi merupakan salah satu lembaga yang sangat strategis dan sentral dalam mendorong percepatan pembangunan masyarakat di daerah. Dengan sejumlah keunggulan yang dimilikinya seperti sumber daya manusia, perangkat kelembagaan yang mapan, serta kemampuan membuat riset dan kajian maka peran perguruan tinggi seyogyanya harus berperan sebagai agen pembangunan (egen of development) disetiap dearah. Dengan potensi-potensi tersebut maka sudah selayaknya bila universitas atau perguruan tinggi didaerah harus mampu mengambil peran dalam pembangunan bukan hanya skala regional namun juga skala nasional bahkan perguruan tinggi didaerah dapat berkembang menjadi salah satu pusat keunggulan (center of excellent).

Perguruan tinggi bukanlah perusahaan yang senantiasa hanya mengejar keuntungan financial, tetapi juga bukan badan amal, melainkan sebuah industri paling vital yang harus dikelola secara efektif dan efisien. Globalisasi telah mendorong timbulnya persaingan yang sangat kompetitif dalam dunia jasa pendidikan. Perguruan tinggi saling berlomba untuk mengembangkan seluruh potensi dan kemampuannya guna menarik minat calon mahasiswa. Kemampuan bersaing tersebut sangat dipengaruhi oleh kinerja manajemen perguruan tinggi yang bersangkutan dalam merencanakan strategi yang berorientasi dalam rangka membangun daya saing yang tinggi.

Untuk membentuk mahasiswa-mahasiswa yang handal yang siap pakai dalam dunia kerja dan berguna dalam pembangunan daerah tidak terlepas dari motivasi mahasiswa dan kontribusi para dosen dalam melaksanakan proses belajar mengajar yang baik.

Perguruan tinggi sebagai penyelenggara pendidikan tinggi harus tampil sebagai leader yang dapat diandalkan dalam pengembangan kemajuan dan peradaban bangsa. Disamping itu perguruan tinggi mempunyai misi yang bersifat nasional dan merupakan infrastruktur untuk melahirkan lulusan atau calon pemimpin bangsa yang berkualitas dan berbudi luhur. Salah satu komponen penting dalam proses pendidikan tinggi adalah Sumber Daya Manusia (SDM) dalam hal ini yaitu dosen, yang juga dibantu komponen lainnya yang mendukung terselenggarakan pendidikan di 
perguruan tinggi.

Hermanto Halil juga menjelaskan bahwa dalam rangka penyelenggaraan OTDA, perguruan tinggi yang ada di daerah, dengan potensinya diharapkan turut serta dan mampu menyusun perencanaan program pembangunan di daerah, guna mengisi ketentuan Ps.1 Ketetapan MPR No. IV/MPR/2000. Potensi daerah yang ada merupakan tantangan untuk meningkatkan taraf hidup masyarakat daerah yang lebih baik antar pemerintah daerah dengan perguruan tinggi dalam menyelesaikan permasalahan yang ada, guna memperlancar dan menyukseskan program pemerintah pusat melalui Program Otonomi Daerah.

Untuk menunjang hal tersebut, selain telah memiliki standarisasi rasio perbandingan antara dosen dan mahasiswa di Universitas Subang maka Universitas Subang dituntut harus memiliki dosen-dosen yang berkualitas dan mampu meningkatkan minat dan motivasi tinggi kepada mahasiswa dalam kuliah sehingga lulusannya mampu bersaing di dunia kerja dan berkarya untuk membangun Kabupaten Subang menjadi lebih baik lagi.

Namun dalam praktek yang terjadi dilapangan dan berdasarkan pengamatan yang dilakukan oleh penulis, ditemukan keaktifan mahasiswa dalam proses belajar mengajar dirasa sangat kurang. Keaktifan merupakan satu penunjang keberhasilan mahasiswa dalam suatu pembelajaran karena keaktifan adalah suatu tanda atau kode bagi dosen bahwa mahasiswa tersebut benar-benar memperhatikan apa yang disampaikannya. Keaktifan mahasiswa bisa dilihat dari seberapa sering dia mengemukakan pendapat dan menjawab pertanyaan dari dosen ketika proses pembelajaran itu berlangsung.

Kinerja Dosen merupakan salah satu faktor yang berpengaruh terhadap keaktifan belajar mahasiswa saat di dalam kelas. Keaktifan yang ditunjukkan mahasiswa pada saat proses belajar mangajar berlangsung, tentunya tidak lepas dari kinerja dosen dalam kegiatan pembelajaran.

Fakta yang sering ditemukan oleh penulis dan terjadi dilapangan adalah mahasiswa kurang berkonsentrasi dalam belajar, tidak mampu menyerap materi yang disampaikan oleh dosen, tidak berani bertanya, kurang aktif dan kurang mampu bekerjasama dalam diskusi yang diadakan, hasil quiz dan ujian-ujian belum begitu memuaskan.

Oleh karena itu, dosen dituntut harus memiliki kemampuan mengajar yang baik agar suasana belajar lebih menyenangkan dan menarik sehingga materi yang disampaikan dapat dicerna dan diterima oleh mahasiswa dengan baik pula. Oleh karena itu kemampuan mengajar dosen juga berpengaruh pada hasil belajar mahasiswa.

Jika kondisi ini masih terus berlangsung maka kecil kemungkinan Universitas Subang mampu melahirkan lulusan yang handal dan memiliki kompetensi yang baik untuk bisa bersaing di dunia kerja karena kinerja kosen merupakan salah satu faktor yang berpengaruh terhadap keaktifan belajar mahasiswa saat di dalam kelas. Keaktifan yang ditunjukkan mahasiswa pada saat proses belajar mangajar berlangsung, tentunya tidak lepas dari kinerja dosen dalam kegiatan pembelajaran. 
Fenomena yang sering terjadi ketika berlangsung proses belajar mengajar yaitu mahasiswa sering mengaku belum siap, tidak mengerjakan tugas yang diberikan, baik individu maupun kelompok minta ditunda pelaksanaan diskusi/ responsi, dan waktu pembelajaran yang lebih singkat dari biasanya. Kondisi inilah yang menjadikan mahasiswa mengalami kesulitan dalam belajar pada diri mahasiswa sehingga ini sangat terkait erat dengan semangat belajar yang dimiliki oleh mahasiswa.

Adapun tujuan dari penelitian yang ingin penulis peroleh adaalah sebagai berikut:

1) Untuk mengetahui dan menganalisis Kompetensi Dosen pada Universitas Subang, Kabupaten Subang Propinsi Jawa Barat Jawa Barat

2) Untuk mengetahui dan menganalisis Karakter Dosen pada Universitas Subang, Kabupaten Subang Propinsi Jawa Barat Jawa Barat

3) Untuk mengetahui dan menganalisis Motode Pembelajaran pada Universitas Subang, Kabupaten Subang Propinsi Jawa Barat Jawa Barat

4) Untuk mengetahui dan menganalisis Kinerja Dosen pada Universitas Subang, Kabupaten Subang Propinsi Jawa Barat Jawa Barat

5) Untuk mengetahui dan menganalisis pengaruh Kompetensi dan Karakter Dosen baik secara simultan maupun parsial terhadap Metode Pembelajaran di Universitas Subang, Kabupaten Subang Propinsi Jawa Barat.

6) Untuk mengetahui dan menganalisis pengaruh Kompetensi dan Karakter Dosen baik secara simultan maupun parsial Terhadap Kinerja Dosen di Universitas Subang, Kabupaten Subang Propinsi Jawa Barat.

7) Untuk mengetahui dan menganalisis pengaruh Metode Pembelajaran terhadap Kinerja Dosen di Universitas Subang, Kabupaten Subang Propinsi Jawa Barat.

\section{Kerangka Teori}

\section{Kompetensi Dosen}

Menurut Triwiyatno (2011), Pengertian kompetensi dapat digambarkan sebagai :"kemampuan untuk melaksanakan tugas, peran dan kemampuan mengintegrasikan pengetahuan, keterampilan-keterampilan, sikap-sikap dan nilai-nilai pribadi dan kemampuan untuk membangun pengetahuan dan keterampilan yang didasarkan pada pengalaman dan pembelajaran yang dilakukan." Hal senada juga dikemukakan oleh Wibowo (2007:325).yang mengemukakan bahwa kompetensi adalah:

"suatu kemampuan untuk melaksanakan atau melakukan suatu pekerjaan yang dilandasi atas keterampilan dan pengetahuan serta di dukung oleh sikap kerja yang dituntut oleh pekerjaan tersebut. Kompetensi merupakan landasan dasar karakteristik orang dan mengindikasikan cara berperilaku atau berpikir, menyamakan situasi,dan mendukung untuk periode waktu cukup lama."

Sedangkan menurut Aris Wijayanto, H. Musa Hubeis, M. Joko Affandi dan Aji Hermawan (2011), memberikan sebuah penjelasan bahwa : 
"bahwa kompetensi merupakan karakteristik dasar (underlying characteristic) yang paling tidak mencakup 5 (lima) jenis karakteristik kompetensi yaitu motif, sikap, konsep diri, pengetahuan dan keterampilan. Hal senada juga dikemukakan oleh Dubois (2004) bahwa kompetensi adalah :

"karakteristik individu yang memiliki kemampuan dan digunakan dengan cara yang konsisten sesuai untuk mencapai kinerja yang diinginkan. Karakteristik ini meliputi pengetahuan, keterampilan, aspek citra diri, motif sosial, sifat, pola pikir dan cara berpikir, perasaan dan pelaksanaan"

Sedangkan menurut UU No. 14/2005 tentang Guru dan Dosen dijelaskan bahwa kompetensi adalah :

"merupakan seperangkat pengetahuan, keterampilan, dan perilaku yang harus dimiliki, dihayati, dikuasai dan diaktualisasikan oleh guru atau dosen dalam melaksanakan tugas keprofesionalan. Kompetensi yang harus dimiliki oleh guru dan dosen meliputi kompetensi pedagogik, kompetensi kepribadian, kompetensi sosial dan kompetensi profesional."

Dari seluruh pendapat para ahli diatas maka penulis dapat menyimpulkan bahwa kompetensi tersebut dapat diartikan sebagai:

"kemampuan diri yang merupakan karakteristik dasar untuk melaksanakan atau melakukan suatu pekerjaan yang dilandasi pengetahuan, keterampilan, dan perilaku yang meliputi kompetensi pedagogik, kompetensi kepribadian, kompetensi sosial dan kompetensi profesional"

Pembahasan pada variabel ini akan dibatasi pada Kompetesni Pedagogik dan Kompetensi Sosial. Adapun alasan pembatasan ini disebabkan oleh dua kompetensi yang lainnya memiliki makna yang hampir sama dengan 2 (dua) variabel lainnya. Tepatnya adalah Kompetensi Kepribadian memiliki makna yang hampir sama dengan Variabel Bebas (X2) yaitu Karakter dan Kompetensi Profesional memiliki makna yang hampir sama dengan Variabel Terikat (Y) yaitu Metode Pembelajaran. Sehingga pemaparan akan lebih detail dijelaskan pada Kompetensi Pedagogik dan Kompetensi Sosial.

\section{Karakter Dosen}

Menurut Dede Mustomi,2018 bahwa:

"Karakter adalah watak, tabiat, akhlak atau kepribadian seseorang yang terbentuk dari hasil internalisasi berbagai kebijakan yang diyakini dan digunakan sebagai landasan untuk cara pandang, berfikir, bersikap dan bertindak" (Dede Mustomi, 2018)

Menurut I Gusti Ayu Komang Mahayanti, Anak Agung Ayu Sri Sriathi, 2017 bahwa;

"Karakteristik individu adalah minat, dimana sikap yang membuat orang puas akan obyek atau ide-ide tertentu. Minat memiliki dampak positif dalam pencapaian kepuasan kerja" 
Konsep lain dikemukakan oleh Sri Lestari, 2009 bahwa;

"Karakter manusia dipengaruhi oleh tiga komponen. Pertama, Pengetahuan Moral (moral knowing), Perasaan Moral (moral affect) dan Tindakan Moral (moral action)."

Sedangkan Manalu, 2014 menjelaskan bahwa;

"Karakter adalah watak, tabiat, akhlak atau kepribadian seseorang yang terbentuk dari hasil internalisasi berbagai kebijakan yang diyakini dan digunakan sebagai landasan untuk cara pandang, berfikir, bersikap dan bertindak."

Dan Menurut Hasan dkk, 2010 bahwa;

"Karakter adalah watak, tabiat, akhlaq, atau kepribadian seseorang yang terbentuk dari hasil adaptasi berbagai kebijakan yang diwujudkan dalam cara pandang, bersikap dan bertindak."

Dengan demikian, dari seluruh pendapat para ahli diatas maka penulis dapat menyimpulkan bahwa Karakter tersebut dapat diartikan sebagai:

"kepribadian seseorang yang terbentuk dari hasil internalisasi yang dipengaruhi Pengetahuan Moral (moral knowing), Perasaan Moral (moral affect) dan Tindakan Moral (moral action) yang diwujudkan melalui cara pandang, bersikap dan bertindal sehingga mampu membuat puas atau tidak terhadap objek atau ide-ide tertentu'

\section{Metode Pembelajaran}

Menurut Samiudin, 2016 bahwa;

"Metode Pembelajaran adalah cara pembentukan atau pemantapan pengertian peserta (penerima informasi) terhadap suatu penyajian informasi/bahan ajar"

Abdurrahman Ginting,2008;42, menjelaskan bahwa;

"Metode pembelajaran didefinisikan sebagai cara atau pola yang khas dalam memanfaatkan berbagai prinsip dasar pendidikan serta berbagai teknik dan sumber daya terkait lainnya agar terjadi proses pembelajaran pada diri pembelajar."

Menurut M. Sobri Sutikno,2009:88 memaparkan bahwa;

"Metode pembelajaran adalah cara-cara menyajikan materi pelajaran yang dilakukan oleh pendidik agar terjadi proses pembelajaran pada diri siswa dalam upaya untuk mencapai tujuan."

Sedangkan menurut Nana Sudjana,2005:76 bahwa;

"Metode pembelajaran adalah, "Metode pembelajaran ialah cara yang dipergunakan guru dalam mengadakan hubungan dengan siswa pada saat berlangsungnya pengajaran."

Dan menurut Tampubolon. Saur, 2014, adalah bahwa; 
"Metode Pembelajaran adalah suatu cara yang digunakan untuk mengimplementasikan rencana yang sudah disusun dalam bentuk kegiatan nyata dan praktis demi mencapai tujuan pembelajaran."

Dengan demikian, dari seluruh pendapat para ahli diatas maka penulis dapat menyimpulkan bahwa Metode Pembelajaran tersebut dapat diartikan sebagai:

"Cara-ca ra penyajian materi yang dilakukan dan dikuasai oleh pengajar dalam menyajikan dan menyampaikan materi agar terjadi proses pembelajaran untuk pembentukan dan pemantapan peserta didik dalam upaya mencapai tujuan pembelajaran."

\section{Kinerja}

Mangkunegara (2001:67) mendefinisikan kinerja sebagai berikut :

"bahwa Kinerja (Performance) adalah hasil kerja secara kualitas dan kuantitas yang dicapai oleh seseorang pegawai dalam melaksanakan tugasnya sesuai dengan tanggungjawab yang diberikan kepadanya."

Menurut Hakim A (2006) mendefinisikan bahwa kinerja sebagai:

"Hasil Kerja yang dicapai oleh individu yang disesuaikan dengan peran atau tugas individu tersebut dalam suatu perusahaan pada suatu periode waktu tertentu, yang dihubungkan dengan suatu ukuran nilai atau standar tertentu dari perusahaan dimana individu tersebut bekerja."

Sedangkan Rivai (2004) mendefinisikan bahwa kinerja adalah:

"merupakan perilaku yang nyata yang ditampilkan oleh setiap orang sebagai prestasi kerja yang dihasilkan oleh karyawan sesuai dengan perannya dalam perusahaan"

Hersey and Blanchard, 1993 juga mengemukakan bahwa kinerja adalah:

"suatu fungsi dari motivasi dan kemampuan. Untuk menyelesaikan tugas atau pekerjaan, seseorang harus memiliki derajat kesediaan dan tingkat kemampuan tertentu. Kesediaan dan keterampilan seseorang tidaklah cukup efektif untuk mengerjakan sesuatu tanpa pemahaman yang jelas tentang apa yang akan dikerjakan dan bagaimana mengerjakannya."

Hal senada juga dikemukakan oleh Hasibuan (2012) bahwa kinerja adalah: "suatu hasil kerja yang dicapai seseorang dalam melaksanakan tugas-tugas yang dibebankan kepadanya yang didasarkan atas kecakapan, pengalaman dan kesungguhan serta waktu."

Dengan demikian, dari seluruh pendapat para ahli diatas maka penulis dapat menyimpulkan bahwa Kinerja tersebut dapat diartikan sebagai:

"Kinerja merupakan hasil kerja secara kualitas dan kuantitas yang dapat dicapai oleh seorang pegawai atas kecakapan, pengalaman dan kesungguhan dalam melaksanakan tugas sesuai dengan tanggung jawab yang diberikan kepadanya." 
Berdasarkan hasil penelitian terdahulu kerangka pemikaran, serta keterkaitan antar variabel, secara konseptual menunjukkan bahwa Kompetensi dan Karakter Dosen berpengaruh pada Metode Pembelajaran serta dampaknya kepada Kinerja Dosen, yang dapat diringkaskan sebagaimana terlihat pada gambar sebagai berikut:

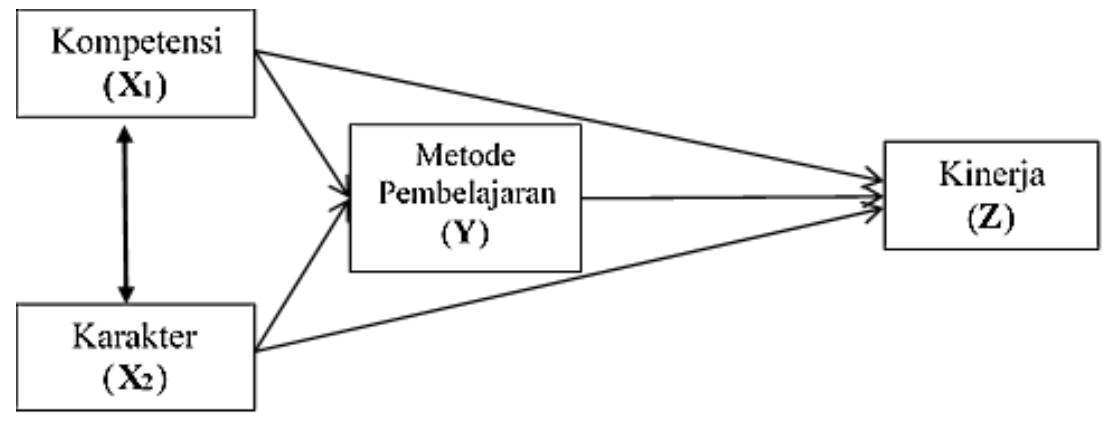

Berikut di bawah ini hipotesis yang bisa dijelaskan dari kerangka pemikiran diatas:

Terdapat pengaruh Kompetensi dan Karakter Dosen baik secara simultan maupun parsial Terhadap Metode Pembelajaran di Universitas Subang, Kabupaten Subang Propinsi Jawa Barat.

Terdapat pengaruh Kompetensi, Karakter Dosen dan Metode Pembelajaran baik secara simultan maupun parsial Terhadap Kinerja Dosen di Universitas Subang, Kabupaten Subang Propinsi Jawa Barat.

Terdapat pengaruh Kompetensi dan Karakter Dosen melalui Metode Pembelajaran terhadap Kinerja Dosen di Universitas Subang, Kabupaten Subang Propinsi Jawa Barat.

\section{Metodelogi Penelitian}

Dalam penelitian ini, penulis menentukan pendekatan yang digunakan untuk bisa mendapatkan hasil yang sesuai dengan tujuan dari penelitian ini. Pendekatan yang dipilih dan digunakan oleh penulis adalah Pendekatan Kuantitatif yaitu pendekatan penelitian yang analisisnya lebih fokus pada data-data numerikal (angka) yang diolah dengan menggunakan metode statistika. Dengan menggunakan pendekatan ini, maka akan diperoleh signifikansi hubungan antar variabel yang diteliti.

Sesuai dengan judul pada penelitian yang dipilih oleh penulis, maka penulis akan menggunakan metode penelitian assosiatif dengan proses kualitatif dan pendekatan action research.

Pendekatan Action research merujuk dari pernyataan Bogdan dan Biklen (1996, dalam Andari Puji Astuti, Fitria Fatichatul Hidayah, 2016) menyatakan bahwa action research adalah sebuah penelitian yang dilakukan secara ilmiah dengan tujuan untuk melakukan koreksi atau evaluasi atas tindakan atau aksi.

Berdasarkan pendapat diatas maka dalam penilitian ini yang diteliti adalah pengaruh Kompetensi dan Karakter Dosen terhadap Metode Pembelajaran serta dampaknya terhadap Kinerja Dosen di Unversitas Subang Kabupaten Subang Propinsi 
Jawa Barat.

Menurut Sugiyono (2007:38, dalam Yahdi Kusnadi \& Mutoharoh, 2016) menjelaskan bahwa Variabel Penelitian pada dasarnya adalah segala sesuatu yang berbentuk apa saja yang ditetapkan oleh peneliti untuk dipelajari sehingga diperoleh informasi tentang hal tersebut, kemudian ditarik kesimpulannya.

Dalam penelitian ini dikenal beberapa macam variabel penelitian. Berdasarkan hubungan antara satu variabel satu dengan variabel yang lain, maka macam - macam variabel yang digunakan dalam penelitian dapat dibedakan menjadi :

\section{Variabel Independen (variabel bebas)}

Variabel ini sering disebut sebagai Variabel Stimulus, Predictor, Antecedent, Variabel Pengaruh, Variabel Perlakuan, Kausa, Treatment, Risiko, atau Variable Bebas. Dalam SEM (Structural Equation Modeling) atau Pemodelan Persamaan Struktural, Variabel Independen disebut juga sebagai Variabel Eksogen. Variabel Bebas adalah variabel yang mempengaruhi atau yang menjadi sebab perubahannya atau timbulnya variabel Dependen (terikat). Dinamakan sebagai Variabel Bebas karena bebas dalam mempengaruhi variabel lain.

\section{Variabel Dependen (Variabel terikat)}

Sering disebut sebagai Variabel Out Put, Kriteria, Konsekuen, Variabel Efek, Variabel Terpengaruh, Variabel Terikat atau Variabel Tergantung. Dalam SEM (Structural Equation Modeling) atau Pemodelan Persamaan Struktural, Variabel Independen disebut juga sebagai Variabel Indogen. Variabel Terikat merupakan Variabel yang dipengaruhi atau yang menjadi akibat karena adanya variabel bebas. Disebut Variabel Terikat karena variabel ini dipengaruhi oleh variabel bebas/variabel independent.

\section{Variabel Intervening}

Dalam hal ini Tuckman (1988) menyatakan "an intervening variable is that factor that theoretically affect the observed phenomenon but cannot be seen, measure, or manipulate". Variabel Intervening adalah Variabel yang secara teoritis mempengaruhi hubungan antara Variabel Bebas dengan Variabel Terikat, tetapi tidak dapat diamati dan diukur. Variabel ini merupakan variabel Penyela/Antara yang terletak diantara Variabel Bebas dan Variabel Terikat, sehingga Variabel Bebas tidak secara langsung mempengaruhi berubahnya atau timbulnya Variabel Terikat.

Dalam penelitian ini variabel-variabel tersebut diatas adalah yaitu:

a) Variabel Bebas $(X)$ yaitu Kompetensi Dosen $\left(X_{1}\right)$ dan Karakter Dosen $\left(X_{2}\right)$

b) Variabel Terkait (Y) adalah Metode Pembelajaran

c) Variabel Intervening (Z) adalah Kinerja Dosen

Menurut Arikunto (1998:144), sumber data adalah subjek darimana suatu data dapat diperoleh. Menurut Sutopo (2006:56-57), sumber data adalah tempat data diperoleh dengan menggunakan metode tertentu baik berupa manusia, artefak, ataupun dokumen-dokumen.

Sumber data penelitian yaitu sumber subjek dari tempat mana data bisa 
didapatkan. Jika peneliti memakai kuisioner atau wawancara didalam pengumpulan datanya, maka sumber data itu dari responden, yakni orang yang menjawab pertanyaan peneliti, yaitu tertulis ataupun lisan. Sumber data berbentuk responden ini digunakan didalam penelitian.

Sumber Data dalam penelitian ini adalah Data Primer adalah data yang diperoleh secara langsung dari responden/sampel yakni Mahasiswa Fakultas Ilmu Administrasi Universitas Subang.

Dalam Penelitian ini, ukuran sampel ditentukan oleh bentuk uji statistik dan yang digunakan adalah analisis jalur (Path Analisis), dimana koefisien jalur pada dasarnya adalah koefisien korelasi. Dengan demikian ukuran sampel minimal untuk analisis jalur ini dapat ditentukan melalui rumus ukuran sampel minimal untuk koefisien korelasi yang dilakukan secara iterative (perhitungan berulang -ulang) dengan langkah sebagai berikut:

Memperkirakan koefisien ( $=$ rho) terkecil antara variabel penyebab yang ada dalam jalur dengan variabel akibat. Hal ini didasarkan pada institusi, kepakaran peneliti dalam bidang yang akan diteliti dan keterangan yang lainnya.

Nilai $\boldsymbol{\rho}$ adalah nilai korelasi yang termasuk kategori rendah/kecil menurut klasifikasi Guilford $(0,20-0,40)$ pada batas atas atau yang paling besar (Sudrajat, 2002)

Menentukan taraf nyata $(\alpha)$ dan kuasa uji (1- $\beta$ ) yang diinginkan dalam penelitian, lihat tabel distribusi normal Tentukan ukuran sampel secara interaktif (Sitepu,1994:17)

literasi pertama mempergunakan rumus:

$$
\begin{gathered}
\mathrm{n}_{1}=\frac{\left(\mathrm{Z}_{(1-\alpha) / 2}+\mathrm{Z}_{1-\beta}\right)^{2}}{\left(\mathrm{U}_{1} \mathrm{p}\right)^{2}} \\
\text { Sedangkan; } \\
{\left[\frac{\mathbf{1 + p}}{\mathbf{1 - p}}\right] \quad \mathrm{U}_{1 \mathrm{p}=1 / 2 \ln }}
\end{gathered}
$$

i. Pada Iterasi kedua rumus yang digunakan adalah:

$$
\mathrm{n}_{2}=\frac{\left(\mathrm{Z}_{(1-\alpha) / 2}+\mathrm{Z}_{1-\beta}\right)^{2}}{\left(\mathrm{U}_{2} \mathrm{p}\right)^{2}}+3
$$

Sedangkan;

$$
\left[\frac{1+p}{1-p}\right] p=\frac{p}{2\left(n_{1}-1\right)} \quad+
$$

ii. Pada Iterasi ketiga rumus yang digunakan adalah:

$$
\begin{aligned}
\mathrm{n}_{3} & =\frac{\left(\mathrm{Z}_{1-\alpha}+\mathrm{Z}_{1-\beta}\right)^{2}}{\left(\mathrm{U}_{3} \mathrm{p}\right)^{2}} \\
{\left[\frac{\mathbf{1 + p}}{\mathbf{1 - p}}\right] \mathrm{p} \mathrm{p} } & \frac{\mathbf{p}_{2\left(\mathrm{n}_{2}-\mathbf{1 )}\right.}}{k a n ;}+
\end{aligned}
$$


Keterangan:

$$
\begin{array}{ll}
\boldsymbol{\rho} & =\text { Koefisien korelasi terkecil yang diharapkan } \\
Z_{(1-\alpha) / 2} & =\text { Konstanta yang diperoleh dari tabel distribusi normal } \\
Z_{1-\beta} & =\text { Konstanta yang diperoleh dari tabel distribusi normal } \\
\alpha & =\text { Kekeliruan Type I } \\
\beta & =\text { Kekeliruan Type II }
\end{array}
$$

Bila ukuran sampel minimal pada iteratif pertama dan kedua harganya sampai dengan bilangan satuannya sama, maka iterasi berhenti. Bila belum sama dilakukan iterasi ketiga dengan menggunakan rumus pada butir $4 \mathrm{~b}$. Demikian seterusnya sampai suatu saat ukuran sampel yang akan ditentukan sudah sama, baru berhenti.

Berdasarkan pada langkah-langkah diatas maka dapat ditentukan nilai $\rho$ sebesar 0,40 . Dan ditentukan nilai $\alpha=0,05$ dan nilai $\beta=0,95$. Dari distribusi normal diperoleh $Z_{(1-\alpha) / 2}=1,96$ dan $Z_{1-\beta}=1,645$. Berikut proses untuk mendapatkan nilai sampel yang diharapkan dalam penelitian ini:

Hitung Iterasi pertama dengan menggunakan rumus:

$$
\begin{gathered}
\mathrm{n}_{\mathbf{1}}=\frac{\left(\mathrm{Z}_{(1-\alpha) / 2}+\mathrm{Z}_{1-\beta}\right)^{2}}{\left(\mathrm{U}_{1 \mathrm{p}}\right)^{2}} \\
\text { Sedangkan; } \\
\frac{\mathbf{1}+\mathbf{p}}{\mathbf{1 - p}]} \mathrm{U}_{1 \mathrm{p}}=1 / 2 \mathrm{ln} \\
=1 / 2 \ln [(1+0,40) /(1-040)] \\
=1 / 2 \ln [2,333] \\
=0,4235 \\
\text { Sehingga nilai } \mathrm{n}_{1} \text { adalah : } \\
\mathrm{n}_{\mathbf{1}}=\frac{\left(\mathrm{Z}_{(1-\alpha) / 2}+\mathrm{Z}_{1-\beta}\right)^{2}}{\left(\mathrm{U}_{1} \mathrm{p}\right)^{2}} \\
=\left[(1,96+1,645)^{2} /(0,4235)^{2}\right] \\
=[12,996025 / 0,17935225] \\
\mathbf{n}_{\mathbf{1}}=72,460
\end{gathered}
$$

Hitung Iterasi kedua dengan menggunakan rumus sebagai berikut:

$$
\begin{gathered}
\mathrm{n}_{2}=\frac{\left(\mathrm{Z}_{(1-\alpha) / 2}+\mathrm{Z}_{1-\beta}\right)^{2}}{\left(\mathrm{U}_{2} \mathrm{p}\right)^{2}}+3 \\
{\left[\frac{\mathbf{1}+\mathbf{p}}{\mathbf{1 - p}}\right] \frac{\mathbf{p}}{\mathbf{2 ( \mathbf { n } _ { \mathbf { 1 } } - \mathbf { 1 } )}}+} \\
=0,4235+[(0,40) / 2(72,460-1)] \\
=0,4235+[(0,40) /(148,92)] \\
=0,4235+0,00268 \\
\mathrm{U}_{2} \mathrm{p}=0,426186
\end{gathered}
$$




$$
\begin{gathered}
\text { Sehingga nilai } \mathrm{n}_{2} \text { adalah : } \\
\mathrm{n}_{2}=\frac{\left(\mathrm{Z}_{(1-\alpha) / 2}+\mathrm{Z}_{1-\beta}\right)^{2}}{\left(\mathrm{U}_{2} \mathrm{p}\right)^{2}}+3 \\
\mathrm{n}_{2}=[(12,996025) /(0,1816345066)] \\
\mathbf{n}_{2}=\mathbf{7 1 , 5 5 1}
\end{gathered}
$$

Hitung Iterasi ketiga dengan menggunakan rumus sebagai berikut:

$$
\begin{gathered}
\mathrm{n}_{3}=\frac{\left(\mathrm{Z}_{(1-\alpha) / 2}+\mathrm{Z}_{1-\beta}\right)^{2}}{\left(\mathrm{U}_{3} \mathrm{p}\right)^{2}} \\
\text { Sedangkan; } \\
{\left[\frac{\mathbf{1}+\mathbf{p}}{\mathbf{1}-\mathbf{p}}\right]^{\frac{\mathbf{p}}{2\left(\mathbf{n}_{2}-\mathbf{1}\right)}}+} \\
\mathrm{U}_{3 \mathrm{p}}=[0,4235]+[(0,40) / 2(71,551-1)] \\
\mathrm{U}_{3} \mathrm{p}=[0,4235]+[(0,40) /(70,551)] \\
\mathrm{U}_{3} \mathrm{p}=[0,4235]+[0,00566] \\
\mathrm{U}_{3} \mathrm{p}=0,42916 \\
\text { Sehingga nilai } \mathrm{n}_{3} \text { adalah }: \\
\mathrm{n}_{3}=\frac{\left(\mathrm{Z}_{1-\alpha}+\mathrm{Z}_{1-\beta}\right)^{2}}{\left(\mathrm{U}_{3} \mathrm{p}\right)^{2}} \\
\mathrm{n}_{3}=[(12,996025) /(0,1842040561)] \\
\mathbf{n}_{3}=70,552
\end{gathered}
$$

Sehingga dari perhitungan diatas dapat ditentukan dan diperoleh ukuran sampel (n) minimal 72 orang, yang sudah dianggap mewakili populasi sehingga penelitian dari sampal dapat menggambarkan karakteristik populasi. Sesuai teknik penentuan sampel seperti telah dikemukakan diatas, maka ukuran sampel dalam penelitian ini adalah minimal 72 orang mahasiswa.

\section{Hasil dan Pembahasan \\ Pengujian Validitas}

Berikut hasil pengujian Validitas dari masing-masing variabel:

Tabel 1

Hasil Uji Validitas Variabel Kompetensi

\begin{tabular}{|c|c|c|c|c|}
\hline Variabel & $\begin{array}{c}\text { Butir } \\
\text { Pernyataan }\end{array}$ & $\begin{array}{c}\text { Korelasi Item } \\
\text { Total (r-hitung) } \\
\text { Tingkat Persepsi }\end{array}$ & $\begin{array}{c}\text { Taraf } \\
\text { Signifikan }\end{array}$ & Kesimpulan \\
\hline \multirow{4}{*}{$\begin{array}{c}\text { Kompetensi } \\
\text { Pedagogik }\end{array}$} & 1 & 0,348 & 0,361 & Tidak Valid \\
\cline { 2 - 5 } & 2 & 0,658 & 0,361 & Valid \\
\cline { 2 - 5 } & 3 & 0,685 & 0,361 & Valid \\
\cline { 2 - 5 } & 4 & 0,630 & 0,361 & Valid \\
\cline { 2 - 5 } & 5 & 0,689 & 0,361 & Valid \\
\hline
\end{tabular}




\begin{tabular}{|c|c|c|c|c|}
\cline { 2 - 5 } & 6 & 0,578 & 0,361 & Valid \\
\cline { 2 - 5 } & 7 & 0,594 & 0,361 & Valid \\
\cline { 2 - 5 } & 8 & 0,697 & 0,361 & Valid \\
\cline { 2 - 5 } & 9 & 0,610 & 0,361 & Valid \\
\cline { 2 - 5 } & 10 & 0,681 & 0,361 & Valid \\
\cline { 2 - 5 } & 11 & 0,491 & 0,361 & Valid \\
\cline { 2 - 5 } & 12 & 0,753 & 0,361 & Valid \\
\hline \multirow{5}{*}{ Sosial } & 13 & 0,704 & 0,361 & Valid \\
\cline { 2 - 5 } & 2 & 0,734 & 0,361 & Valid \\
\cline { 2 - 5 } & 2 & 0,681 & 0,361 & Valid \\
\cline { 2 - 5 } & 3 & 0,511 & 0,361 & Valid \\
\cline { 2 - 5 } & 4 & 0,544 & 0,361 & Valid \\
\cline { 2 - 5 } & 7 & 0,293 & 0,361 & Tidak Valid \\
\cline { 2 - 5 } & 8 & 0,486 & 0,361 & Valid \\
\cline { 2 - 5 } & 9 & 0,536 & 0,361 & Valid \\
\hline
\end{tabular}

Berdasarkan tabel 4.13 dapat ditarik kesimpulan bahwa terdapat instrumen pertanyaan pada variabel Kompetensi yang tidak valid karena r-hitung $<0,361$.

\section{Tabel 2}

Hasil Uji Validitas Variabel Karakter

\begin{tabular}{|c|c|c|c|c|}
\hline Variabel & $\begin{array}{c}\text { Butir } \\
\text { Pernyataan }\end{array}$ & $\begin{array}{c}\text { Korelasi Item } \\
\text { Total (r-hitung) } \\
\text { Tingkat Persepsi }\end{array}$ & $\begin{array}{c}\text { Taraf } \\
\text { Signifikan }\end{array}$ & Kesimpulan \\
\hline \multirow{5}{*}{ Karakter } & 1 & 0,703 & 0,361 & Valid \\
\cline { 2 - 5 } & 2 & 0,721 & 0,361 & Valid \\
\cline { 2 - 5 } & 3 & 0,671 & 0,361 & Valid \\
\cline { 2 - 5 } & 4 & 0,700 & 0,361 & Valid \\
\cline { 2 - 5 } & 5 & 0,667 & 0,361 & Valid \\
\cline { 2 - 5 } & 6 & 0,834 & 0,361 & Valid \\
\cline { 2 - 5 } & 8 & 0,569 & 0,361 & Valid \\
\cline { 2 - 5 } & 9 & 0,654 & 0,361 & Valid \\
\cline { 2 - 5 } & 10 & 0,749 & 0,361 & Valid \\
\cline { 2 - 5 } & 11 & 0,633 & 0,361 & Valid \\
\hline
\end{tabular}

Berdasarkan tabel 4.14 dapat ditarik kesimpulan bahwa seluruh instrumen variabel Karakter valid karena r-hitung $>0,361$

Tabel 3

\section{Hasil Uji Validitas Variabel Metode Pembelajaran}

\begin{tabular}{|c|c|c|c|c|}
\hline Variabel & $\begin{array}{c}\text { Butir } \\
\text { Pernyataan }\end{array}$ & $\begin{array}{c}\text { Korelasi Item } \\
\text { Total (r-hitung) } \\
\text { Tingkat Persepsi }\end{array}$ & $\begin{array}{c}\text { Taraf } \\
\text { Signifikan }\end{array}$ & Kesimpulan \\
\hline \multirow{2}{*}{ Loyalitas } & 1 & 0,570 & 0,361 & Valid \\
\cline { 2 - 5 } & 2 & 0,644 & 0,361 & Valid \\
\hline
\end{tabular}




\begin{tabular}{|c|c|c|c|}
\hline 3 & 0,679 & 0,361 & Valid \\
\hline 4 & 0,200 & 0,361 & Tidak Valid \\
\hline 5 & 0,667 & 0,361 & Valid \\
\hline 6 & 0,560 & 0,361 & Valid \\
\hline 7 & 0,642 & 0,361 & Valid \\
\hline 8 & 0,425 & 0,361 & Valid \\
\hline 9 & 0,697 & 0,361 & Valid \\
\hline 10 & 0,669 & 0,361 & Valid \\
\hline
\end{tabular}

Berdasarkan tabel diatas dapat ditarik kesimpulan bahwa terdapat instrumen variabel Metode Pembelajaran yang tidak valid karena r-hitung <0,3.

\section{Pengujian Reliabilitas}

Pengujian Reliabilitas dilakukan dengan internal consistency atau derajat ketepatan jawaban. Untuk pengujian reliabilitas ini digunakan software SPSS 20.0. Uji reliabilitas tersebut dilakukan dengan menggukanan rumus Alpha Cronbach sebagai berikut:

$$
r_{11}=\left[\frac{k}{k-1}\right]\left[1-\frac{\Sigma \sigma_{b}{ }^{2}}{\sigma^{2}{ }_{t}}\right]
$$

Keterangan :

$r_{11} \quad=\quad$ Reliabilitas instrumen

$k=$ Banyaknya butir pernyataan

$\Sigma \sigma_{b}^{2}=\quad$ Jumlah varians butir

$\sigma_{t}^{2}=$ Varians total

Menurut Sekaran (2010: 182) suatu instrument alat ukur dikatakan reliabel dan bisa diproses pada tahap selanjutnya jika nilai koefisien $r \geq 0,7$. Jika instrument alat ukur memiliki nilai koefisien $r<0,7$ maka alat ukur tersebut tidak reliabel.

\section{Tabel 4}

\section{Hasil Uji Reliabilitas Pertanyaan Kuesioner}

\begin{tabular}{|c|c|c|c|c|}
\hline Variabel & $\begin{array}{c}\text { Cronbach's } \\
\text { Alpha }\end{array}$ & $\begin{array}{c}\text { Cronbach's Alpha } \\
\text { Based on } \\
\text { Standardized Items }\end{array}$ & $\begin{array}{c}\text { N of } \\
\text { Items }\end{array}$ & Kesimpulan \\
\hline Kompetensi & 0,914 & 0,700 & 22 & Reliabel \\
\hline Karakter & 0,889 & 0,700 & 11 & Reliabel \\
\hline Metode Pembelajaran & 0,759 & 0,700 & 10 & Reliabel \\
\hline Kinerja Dosen & 0,816 & 0,700 & 11 & Reliabel \\
\hline
\end{tabular}

Berdasarkan tabel diatas dapat ditarik kesimpulan bahwa seluruh instrumen variabel Kompetensi, Karakter, Metode Pembelajaran dan Kinerja Dosen reliabel karena nilai $r>0,7$. 
Analisis Jalur (Path Analisys)

Pengujian Substruktur 1, Kompetensi (X1) dan Karakter (X2) secara Simultan terhadap Metode Pembelajaran (Y)

Tabel 5

\begin{tabular}{|l|r|r|r|r|r|}
\hline \multicolumn{1}{|c|}{ Model } & Sum of Squares & \multicolumn{1}{c|}{ df } & Mean Square & F & \multicolumn{1}{c|}{ Sig. } \\
\hline $1 \quad$ Regression & 1250.380 & 2 & 625.190 & 37.718 & $.000^{\mathrm{b}}$ \\
Residual & 1607.810 & 97 & 16.575 & & \\
Total & 2858.191 & 99 & & & \\
\hline
\end{tabular}

a. Dependent Variable: METODE PEMBELAJARAN

b. Predictors: (Constant), KARAKTER, KOMPETENSI

Sumber : Hasil pengolahan data statistik dengan SPSS

Pada tabel di atas dapat kita ketahui bahwa nilai signifikansi < nilai signifikansi yang ditetapkan yaitu 0,000<0,05, maka Ho ditolak. Dan ini berarti bahwa Hasil pengujiannya signifikan, yang berarti secara keseluruhan variabel Kompetensi dan Karakter berpengaruh secara signifikan terhadap Metode pembelajaran.

Untuk melihat pengaruh secara simultan tentang pengaruh dari luar selain $\mathrm{X}_{1}$ dan $\mathrm{X}_{2}$, kita lihat pada model summary output SPSS dibawah ini dimana besarnya nilai $\mathrm{R}$ Square adalah 0,437.

\section{Tabel 6}

\begin{tabular}{|l|c|r|r|r|}
\hline Model & R & R Square & $\begin{array}{c}\text { Adjusted R } \\
\text { Square }\end{array}$ & $\begin{array}{c}\text { Std. Error of } \\
\text { the Estimate }\end{array}$ \\
\hline 1 & $.661^{\mathrm{a}}$ & .437 & .426 & 4.07129 \\
\hline
\end{tabular}

a. Predictors: (Constant), KARAKTER, KOMPETENSI

Sumber : Hasil pengolahan data statistik dengan SPSS

Berdasarkan tabel di atas terlihat bahwa variabel Kompetensi (X1) dan Karakter (X2) secara simultan memberikan pengaruh sebesar 0,437. Sementara itu pengaruh lain sebesar 0,563 ditentukan oleh variable lain yang tidak dapat dijelaskan pada penelitian ini.

Pengujian Substruktur 1, Kompetensi (X1) dan Karakter (X2) secara Parsial terhadap Metode Pembelajaran (Y) 
Tabel 7

Nilai Koefisien Pengujian Substruktur 1

\begin{tabular}{|c|c|c|c|c|c|}
\hline \multicolumn{6}{|c|}{ Coefficients $^{a}$} \\
\hline \multirow[b]{2}{*}{ Model } & \multicolumn{2}{|c|}{$\begin{array}{c}\text { Unstandardized } \\
\text { Coefficients }\end{array}$} & \multirow{2}{*}{$\begin{array}{l}\text { Standardized } \\
\text { Coefficients } \\
\text { Beta }\end{array}$} & \multirow[b]{2}{*}{$\mathrm{t}$} & \multirow[b]{2}{*}{ Sig. } \\
\hline & B & Std. Error & & & \\
\hline 1 (Constant) & 10.216 & 2.832 & & 3.607 & .000 \\
\hline KOMPETENSI & .230 & .053 & .458 & 4.347 & .000 \\
\hline KARAKTER & .210 & .086 & .256 & 2.435 & .017 \\
\hline
\end{tabular}

Dependent Variable: METODE PEMBELAJARAN

Sumber : Hasil pengolahan data statistik dengan SPSS

Berdasarkan hasil pengujian secara keseluruhan bahwa hasil yang didapatkan adalah signifikan, maka kemudian kita akan melihat pengaruh $\mathrm{X}_{1}$ dan $\mathrm{X}_{2}$ terhadap $\mathrm{Y}$ secara sendiri atau masing- masing atau parsial dengan menggunakan uji $\mathrm{T}$ tetapi pada penelitian ini, dasar pengambilan keputusan, untuk menentukan hipotesis adalah berdasarkan nilai signifikansinya dengan kriteria uji nya sebagai berikut:

a. Jika hasil nilai signifikansi > nilai signifikansi yang ditetapkan, maka Ho diterima

b. Jika hasil nilai signifikansi < nilai signifikansi yang ditetapkan, maka Ho ditolak

Dan untuk melihat seberapa besarnya pengaruh bisa dilihat dari nilai beta atau standardized coefficients.

Pada tabel di atas dapat kita ketahui bahwa semua nilai signifikansi < nilai signifikansi yang ditetapkan yaitu 0,000<0,05 dan 0,017<0,05, maka Ho ditolak. Hal ini berarti Variabel Kompetensi (X1) memberikan pengaruh yang signifikan terhadap Metode pembelajaran (Y). Begitu juga Variabel Karakter (X2) memberikan pengaruh yang signifikan terhadap Metode pembelajaran (Y).

\section{Pengujian Substruktur 2, Pengaruh Metode pembelajaran (Y) terhadap Kinerja Dosen (Z)}

Pada Pengujian Substruktur 2 ini, Hipotesis yang diajukan adalah sebagai berikut, "terdapat pengaruh Metode pembelajaran terhadap Kinerja Dosen" dengan rumusan dengan hipotesis statistiknya sebagai berikut:

Ho : $\rho z y=0$

Metode pembelajaran tidak berpengaruh secara signifikan terhadap Kinerja Dosen" H1 : $\rho z y \neq 0$

Metode pembelajaran berpengaruh secara signifikan terhadap kinerja dosen"

Pada penelitian ini, dasar pengambilan keputusan, untuk menentukan hipotesis adalah berdasarkan nilai signifikansinya dengan kriteria uji nya sebagai berikut:

Jika hasil nilai signifikansi > nilai signifikansi yang ditetapkan, maka Ho diterima Jika hasil nilai signifikansi < nilai signifikansi yang ditetapkan, maka Ho ditolak 
Berikut dibawah ini ditampilkan hasil penghitungan pengujian yang tampak pada tabel berikut ini: Pada tabel di atas dapat kita ketahui bahwa nilai signifikansi < nilai signifikansi yang ditetapkan yaitu 0,000<0,05, maka Ho ditolak. Hal ini berarti bahwa Variabel Metode Pembelajaran (Y) memberikan pengaruh yang signifikan terhadap Kinerja Dosen (Z).

Pengujian Pengaruh Kompetensi (X1), Karakter (X2) dan Metode pembelajaran (Y) terhadap Kinerja Dosen $(Z)$ secara simultan.

\section{Tabel 8}

Model Summary

\begin{tabular}{|l|r|r|r|r|}
\hline $\begin{array}{l}\text { Mode } \\
1\end{array}$ & \multicolumn{1}{|c|}{$\mathrm{R}$} & R Square & $\begin{array}{c}\text { Adjusted R } \\
\text { Square }\end{array}$ & $\begin{array}{l}\text { Std. Error of } \\
\text { the Estimate }\end{array}$ \\
\hline 1 & $.742^{\mathrm{a}}$ & .550 & .521 & 4.41386 \\
\hline
\end{tabular}

a. Predictors: (Constant), M. PEMBELAJARAN, KARAKTER, KOMPETENSI

Berdasarkan output SPSS pada tabel model summary dibawah ini didapat $\mathrm{R}^{2}$ sebesar 0,550 maka pe ngaruh 1 ain $\rho \times 1 \times 2=1-0,550$ yaitu 0,450,

Berdasarkan tabel di atas terlihat bahwa variabel Kompetensi (X1), Karakter (X2), dan Metode Pembelajaran (Y) secara simultan memberikan pengaruh sebesar 0,550. Sementara itu pengaruh lain sebesar 0,450 ditentukan oleh variable lain yang tidak dapat dijelaskan pada penelitian ini.

Pengujian Pengaruh Kompetensi (X1), Karakter (X2) dan Metode pembelajaran (Y) secara parsial terhadap Kinerja Dosen

\section{Tabel 9}

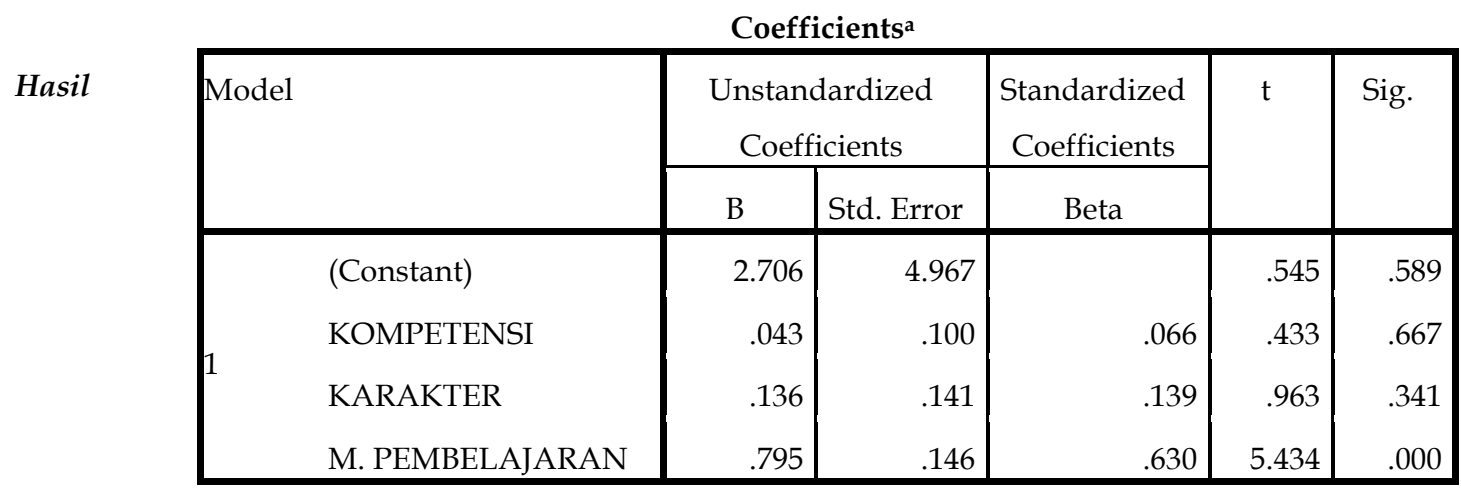

Sumber :

a. Dependent Variable: KINERJA DOSEN

pengolahan data statistik dengan SPSS 
Pada tabel di atas dapat kita ketahui bahwa semua nilai signifikansi < nilai signifikansi yang ditetapkan yaitu 0,05, maka keputusan Ho sebagai berikut:

Nilai signifikan Variabel Kompetensi (X1) adalah 0,667 sehingga Ho pada variabel ini diterima yang memberikan arti bahwa secara parsial Variabel Kompetensi (X1) tidak memberikan pengaruh yang signifikan terhadap Kinerja (Z)

Nilai signifikan Variabel Karakter (X2) adalah 0,341 sehingga Ho pada variabel ini diterima yang memberikan arti bahwa secara parsial Variabel Karakter (X2) tidak memberikan pengaruh yang signifikan terhadap Kinerja ( $Z$ )

Nilai signifikan Variabel Metode Pembelajaran (Y) adalah 0,000 sehingga Ho pada variabel ini ditolak yang memberikan arti bahwa Variabel Metode Pembelajaran $(Y)$ memberikan pengaruh yang signifikan terhadap Kinerja (Z)

\section{Hasil Perhitungan Analisis Korelasi}

Dalam metode analisis jalur, untuk mencari hubungan kausal atau pengaruh variabel- variabel penelitian, terlebih dahulu dihitung matriks korelasi dari variabelvariabel Kompetensi (X1), Karakter (X2), Metode Pembelajaran (Y) terhadap Kinerja Dosen (Z). Dimana nilai tersebut dapat kita lihat melalui output SPSS sebagai berikut:

Tabel 10

\section{Perhitungan Analisis Korelasi}

\begin{tabular}{|c|c|c|c|c|c|}
\hline \multicolumn{6}{|c|}{ Correlations } \\
\hline & & KOMPETENSI & KARAKTER & $\begin{array}{c}\text { METODE } \\
\text { PEMBELAJARAN }\end{array}$ & $\begin{array}{l}\text { KINERJA } \\
\text { DOSEN }\end{array}$ \\
\hline \multirow[t]{3}{*}{ KOMPETENSI } & $\begin{array}{l}\text { Pearson } \\
\text { Correlation }\end{array}$ & 1 & $.691^{* *}$ & $.635^{\star *}$ & $.622^{* *}$ \\
\hline & Sig. (2-tailed) & & .000 & .000 & .000 \\
\hline & $\mathrm{N}$ & 100 & 100 & 100 & 100 \\
\hline \multirow[t]{3}{*}{ KARAKTER } & $\begin{array}{l}\text { Pearson } \\
\text { Correlation }\end{array}$ & & 1 & $.573^{* *}$ & \\
\hline & Sig. (2-tailed) & .000 & & .000 & .000 \\
\hline & $\mathrm{N}$ & 100 & 100 & 100 & 100 \\
\hline \multirow[t]{3}{*}{$\begin{array}{l}\text { METODE } \\
\text { PEMBELAJARAN }\end{array}$} & $\begin{array}{l}\text { Pearson } \\
\text { Correlation }\end{array}$ & $.635^{\star *}$ & $.573^{* *}$ & 1 & $.745^{\star *}$ \\
\hline & Sig. (2-tailed) & .000 & .000 & & .000 \\
\hline & $\mathrm{N}$ & 100 & 100 & 100 & 100 \\
\hline \multirow[t]{3}{*}{ KINERJA DOSEN } & $\begin{array}{l}\text { Pearson } \\
\text { Correlation }\end{array}$ & $.622^{* *}$ & $.573^{* *}$ & $.745^{\star *}$ & 1 \\
\hline & Sig. (2-tailed) & .000 & .000 & .000 & \\
\hline & $\mathrm{N}$ & 100 & 100 & 100 & 100 \\
\hline
\end{tabular}

**. Correlation is significant at the 0.01 level (2-tailed).

Berdasarkan semua analisis di atas dapat disimpulkan bahwa Kompetensi dan 
Karakter berpengaruh terhadap Metode Pembelajaran dan berimplikasi secara signifikan terhadap Kinerja Dosen. Hasil analisis tersebut digambarkan dalam diagram jalur seperti berikut :

\section{Gambar 1}

\section{Kerangka hubungan kausal empiris antara Variabel}

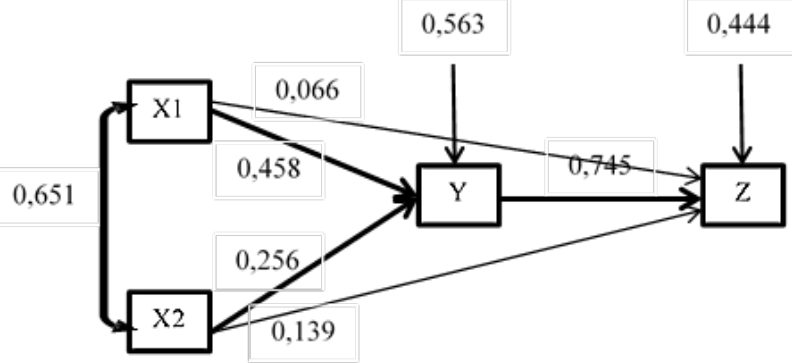

Berdasarkan gambar diagram di atas, kerangka hubungan kausal empiris antara Kompetensi $\left(\mathrm{X}_{1}\right)$, Karakter $\left(\mathrm{X}_{2}\right)$ dan Metode Pembelajaran $(\mathrm{Y})$ terhadap Kinerja Dosen (Z) dibuat model struktur sebagai berikut:

$$
\begin{aligned}
& Y=0.458 X_{1}+0.256 X_{2}+\varepsilon_{1} \\
& Z=0.745 Y+\varepsilon_{2}
\end{aligned}
$$

\section{Kesimpulan}

Berdasarkan hasil penelitian yang telah dilakukan untuk mengetahui Pengaruh Kompetensi dan Karakter Dosen terhadap Metode Pembelajaran serta dampaknya terhadap Kinerja Dosen, maka dapat ditarik kesimpulan sebagai berikut:

Terdapat pengaruh Kompetensi Dosen terhadap Metode Pembelajaran yang diberikan kepada mahasiswa dan berdampak kepada kinerja dosen dalam menjalankan fungsi dan tugasnya sehari-hari. Terdapat pengaruh Karakter Dosen terhadap Metode Pembelajaran diberikan kepada mahasiswa dan memberikan dampak terhadap kinerja dosen dalam menjalankan fungsi dan tugasnya sehari-hari.Dengan pemilihan Metode Pembelajaran yang baik dan sesuai dengan kondisi yang ada serta didukung oleh Kompetensi serta Karakter dosen akan berdampak terhadap Kinerja Dosen.

Kinerja dosen Universitas Subang akan bisa terlihat dan sekaligus bisa di evaluasi melalui peningkatan Kompetensi dan Karakter Dosen yang akhirnya mampu memilih metode pembelajaran yang akan diberikan kepada mahasiswa. Kompetensi dan Karakter Dosen sangat berperan dalam pemilihan Metode Pembelajaran yang diberikan dalam proses perkuliahanSecara tidak langsung Kompetensi dan Karakter Dosen juga berperan dalam peningkatan Kinerja Dosen. Atas pengaruh Kompetensi dan Karakter Dosen, Metode Pembelajaran sangat berperan dalam peningkatan Kinerja 
Dosen Universitas Subang. Atas pengaruh Kompetensi dan Karakter Dosen, Metode Pembelajaran sangat berperan dalam peningkatan Kinerja Dosen Universitas Subang.

Setelah Peneliti melakukan penelitian mengenai pengaruh Kompetensi dan Karakter Dosen terhadap Metode Pembelajaran serta dampaknya pada Kinerja Dosen di Universitas Subang maka berikut beberapa saran atau rekomendasi yang ingin disampaikan oleh peneliti: Di harapkan Dosen Universitas Subang mampu menghidupkan suasana kelas saat proses perkuliahan dengan melakukan pemilihan metode pembelajaran yang lebih variatif dan inovatif yang didukung dengan kompetensi diri dan kekuatan karakter dosen yang lebih baik. Diharapkan Dosen Universitas Subang bisa menempuh jenjang pendidikan yang lebih tinggi dan berbagai pelatihan untuk memenuhi kebutuhan ilmu yang terus berkembang dan dapat meningkatkan kinerja dosen guna membantu mahasiswa meningkatkan pengetahuan. Selain itu, Dosen dalam mengajar juga diharapkan selalu memberikan informasi yang detail dan jelas terkait dengan keilmuannya, salah satunya caranya dengan bedah jurnal hasil penelitian terbaru baik jurnal nasional maupun internasional. Dosen, sebagai tenaga pendidik dalam perguruan tinggi dituntut meningkatkan kualitas diri dengan memahami dan meningkatkan kompetensi diri, memiliki karakter yang kuat dalam mengajar, inovasi dan kreatifitas yang tinggi sehingga mampu melakukan pemilihan metode pembelajaran dan berdampak kepada proses pembelajaran yang dilaksanakan dalam perguruan tinggi berjalan dengan baik, secara efektif dan efisien. Seorang tenaga pendidikan yang memiliki profesionalisme yang rendah dan karakter yang lemah akan menghasilkan proses pembelajaran yang kurang baik, yang berakibat jeleknya kinerja dosen sehingga akan menurunkan prestasi belajar mahasiswa serta dapat memberikan dampak buruk pada mutu pendidikan di perguruan tinggi.

Disarankan kepada penelitian-penelitian selanjutnya, yang berkaitan dengan pengaruh Kompetensi dan Karakter Dosen terhadap Metode Pembelajaran serta dampaknya pada Kinerja Dosen di Universitas Subang agar dapat melakukan penelitiannya dengan menambah variabel-variabel diluar variabel yang sudah ada. Sebab dari hasil analisis yang diperoleh, ada variabel-variabel lain yang juga mempengaruhi Metode Pembelajaran serta dampaknya terhadap Kinerja Dosen di Universitas Subang.Setelah menyelesaikan kegiatan penelitian ini, peneliti memiliki keterbatasan dalam segi waktu, biaya, sumber, pemikiran dan lain sebagainya. Oleh karena itu, kepada peneliti selanjutnya yang ingin melakukan penelitian yang sama mengenai pengaruh Kompetensi dan Karakter Dosen terhadap Metode Pembelajaran serta dampaknya pada Kinerja Dosen di Universitas Subang, diharapkan mampu memperbaiki keterbatasan dan kelemahan peneliti khususnya yang berkaitan dengan pemilihan teori dalam menganalisis variabel yang diteliti.

\section{Referensi}

Agustina, Risambessy, Pengaruh Diklat, Disiplin Kerja dan Kompetensi terhadap Kinerja Pegawai Balai Diklat Keagamaan Ambon, Jurnal SOSOQ, Volume 5, Nomor 2, Februari 2018 
Almasri, Nazar,M., Manajemen Sumber Daya Manusia:Imlementasi dalam Pendidikan Islam, Jurnal Penelitian Sosial Keagamaan, Vol.19, No.2, Juli-Desember 2016

Ataunur, Ilman, Pengaruh Kompetensi dan Pelatihan Terhadap Kinerja Karyawan PT. Adaro Energy Tbk, Telaah Bisnis, Volume 16, Nomor 2, Desember 2015

Azmy, Ahmad, Pengambangan Kompetensi Sumber Daya Manusia untuk Mencapai Career Ready Profesional di Universitas Tanri Abeng, Binus Business Review, Vol. 6, 220-232, No. 2, Agustus 2015

Edy, La, Pengaruh Diklat, Disiplin Kerja dan Kompetensi Terhadap Kinerja Pegawai Balai Diklat Keagamaan Ambon, Jurnal SOSOQ, Volume 5, Nomor 2, Februari 2018

Effendi, Usman, Penilaian Kinerja Karyawan Bagian Personalia Berdasarkan Kompetensi dengan Metode 360 Derajat di PG Kebon Agung - Malang, Jurnal Industri, Hal. 31-40Vol. 4, No. 1

Fathorrahman, Kompetensi Pedagogik, Profesional, Kepribadian dan Kompetensi Sosial Dosen, Jurnal Akademik, Vol. 15, No. 1, Februari 2017

Hasibuan, Malayu, Manajemen Sumber Daya Manusia, Edisi Revisi, Cetakan kedua puluh satu, Maret 2017

Hamdani, Hubungan Kompetensi Pedagogik dna Motivasi Mengajar dengan Hasil Belajar Siswa Kelas XI pada mata Pelajaran Fikih di MAN 2 Model Medan, Jurnal Ansiru, Nomor 1 Volume 1, Juni 2017/43.

Hati, Wahyu, Shinta, Pengaruh Kepemimpinan dan Kinerja Dosen terhadap Mutu Pelayanan di Politeknik Negeri Batam, Jurnal Ekonomi dan Bisnis Islam, Iqtishoduna, Fakultas Ekonomi UIN Maulana Malik Ibrahim Malang Vol.9, No.2, Tahun 2013

Hakim, Abdul. Wuryanto, Model Peningkatan Kinerja Karyawan melalui Peran Komunikasi dan Motivasi serta Pengaruhnya terhadap Kepuasan Kerja, Ekobis Vol.15, No.2, 1-18, Juli 2014

Ibrahim, Sakdiah, \& Usman, Nasir, \& Balqis, Putri, Kompetensi Pedagogik Guru dalam Meningkatkan Motivasi Belajar Siswa pada SMPN 3 Ingin Jaya Kabupaten Aceh Besar, Jurnal Administrasi Pendidikan Pasca Sarjana Universitas Syiah Kuala, ISSN 2302-0156, pp.25-38

Prabowo, Setya, Ady, Pergua, Pengaruh Kemampuan Dan Motivasi Terhadap Kinerja karyawan Akunting pada Kantor Konsultan Pajak Pakar Penata Usaha Periode 2012, Sekolah Tinggi Ilmu Ekonomi Widya Manggala

Kusnadi, Yahdi, Pengaruh Keterimaan Aplikasi Pendaftaran Online Terhadap Jumlah Pendaftar di Sekolah Dasar Negeri Jakarta, Jurnal Paradigma, Vol. XVIII, No. 2, September 2016. 
Mustomi, Dede, Persepsi Tentang Karakteristik Dosen Terhadap Motivasi Belajar Mahasiswa, Widya Cipta, Vol. II, Nomor 1, Maret 2018

Santoso, Anang, Pendidikan Karakter Kerjasama dalam Pembelajaran Siswa Sekolah Dasar pada Kurikulum 2013, Jurnal Teori dan Praktis Pembelajaran IPS, P ISSN 2503-1201 \& E ISSN 2503-5347, Vol. 1, No. 1, April 2016

Samiudin, Peran Metode untuk Mencapai Tujuan Pembelajaran, Jurnal Studi Islam, Vol.11, Nomor 2, Desember 2016

Seprini, Strategi Meningkatan Kompetensi Dosen Universitas Pasir Pangaraian Melalui Pendidikan dan Pelatihan, Jurnal Ilmiah Cano Eknomos, Vol. 3, No. 2, Juli 2014

Saputri, Dityar, Dwi, Tisyantari, Pengaruh Karakteristik Individu, Pekerjaan, dan Lingkungan Kerja Terhadap Kinerja Karyawan, Jurnal Ilmu dan Riset Manajemen, ISSN. 2461-0593, Vol. 5, Nomor 8, Agustus 2016

Sholehatusya' diah, Pengaruh Kompetensi Kerja Terhadap Kinerja Karyawan di Kantor PT. Kitadin Tenggarong Seberang, e-Journal Administrasi Negara Volume 5, Nomor 2: 5789 -5802, 2017

Sugiyono, 2017 Metode Penelitian Kuantitatif, Cetakan Pertama, CV. Alfabeta, Bandung, 2018

Sugiyono, Metode Penelitian Kuantitatif, Kualitatif dan R\&D, Cetakan ke-25, CV. Alfabeta, Bandung, 2017

Sarwono, Jonathan, Mengenal Path Analysis: Sejarah, Pengertian dan Aplikasi, Jurnal Ilmiah Manajemen Bisnis, Vol. 11, No.2, November 2011:285-296 